\title{
設計用模擬地震動飞関する研究
}

一その 2 模擬地震動の作成に必要な地震動特性についての解析

$\begin{array}{lllll}\text { 正会員 } & \text { 渡 } & \text { 部 } & \text { 丹*1 } \\ \text { 正会員 } & \text { 藤 } & \text { 堂 } & \text { 正 } & \text { 喜*2 }\end{array}$

§1.はじめに

前報（その1)1) で得られたようなマグニチュード， 震源距離（多くは，地盤条件も含まれる）をパラメータ とした地震動の推定ピーク值は，現在までに観測された 地震動の平均的な值としての応答スペクトル ${ }^{2), 3)}$ の強さ を決定する場合においても活用されている。この場合， マグニチュードや震源距離に関係なく，スペクトル形状 を一定とした正規化応答スペクトル值を仮定して，地震 動のピーク值によって，適宜スペクトル強さを決定して いる。しかし，地震動のスペクトルの卓越した周期はマ グニチュードや震源距㕍によって変化するものであり ${ }^{4}$, それらの効果を無視した正規化スペクトルを用いること は，耐震設計上，合理的なものとはならない場合もあ る。

上記の観点から，マグニチュードや震源距離の変数 を, 直接, 地震動のスペクトル值の統計解析に導入した

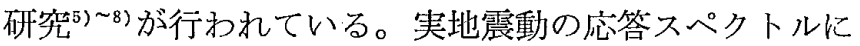
ついて研究した，小林 ${ }^{5)}$ ，および片山 ${ }^{67}$ の研究では，ス ペクトルの 各固有周期について，（その1）で紹介した ピーク值の推定式，式 (4-1) と式 (4-2) と同様の表現 式をそれぞれ応答スペクトルに適用している。すなわ ち，小林らの表現方法はマグニチュードと震源距離につ いて連続関数であり, 片山らの研究では応答スペクトル は上記の変数についてステップ関数とされている。它た 筆者の一人と大㥓らは岩盤上の剛構造物を対象にした 設計用応答スペクトルを提案している。この提案では， 擬似速度応答スペクトルについて速度また加速度を一定 とみなす領域などを定める周期とその周期におけるスペ クトル值を，マグニチェード $6,7,8$ と至近距離，近距 離，遠距離（この距離はマグニチュード每に変化してい る）に関して $3 \times 3$ のマトリクスを構成し，それの各々 について上記の制御值を定義している。また他に断層も デルによる理論的なアプローチが，太田らによって行わ れている99。

本報告では，2 章において，我が国の硬質地盤で観測

*1 建設省建築研究所 国際地震工学部部長・工博

*2 只田建設

(昭和 56 年 2 月 24 日本稿受理・討論期限昭和 57 年 5 月末日)
された地震動を用いて，それらの応答スペクトルを統計 的に解析する。更に，それらの結果を使って，応答スペ クトルの関数化を試みて, 硬質地盤における地震動のス ペクトル特性のマグニチュード，抢よび震源距離に対す る依存性を明らかにする。それに加え, 模擬地震動の作 成に必要なパラメータである，地震動の継続時間と確定 強度関数に関する検討を 3 章で行う。 3 次元地震動の基: 本的な性質を知るために上下動成分についても検婛与 る。4 章では地震動の主軘 ${ }^{10} の$ 特性について考察を加え る。

\section{§2. 岩盤における地震動のスペクトル特性}

小林らの仮定したマグニチュード $(M)$ と震源距﨎 $(x ; \mathrm{km})$ を変数とした速度応答 スペクトルについての 基本式は次式で表わされる

$$
S_{v}^{0.05}(S, M, x, T)=G_{\mathrm{S}} \cdot 10^{A(T) M-B(T) \log x-C(T)}
$$

ここで, $S_{v}{ }^{0.05}(\mathrm{~cm} / \mathrm{sec})$ は減衰定数 $5 \%$ の速度応答スペ クトルであり， $A(T), B(T)$ 抢よび $C(T)$ 沖固有周 期 $T$ (sec) の関数であり，これら 3 つの係数から地震基 盤とみなしたある地中内での標淮速度応答スペクトルが 求めら机る $G_{\mathrm{S}}(T)$ 峈各地点固有の係数であり上記の 地震基盤に㧍けるスペクトルから地表に拄けるスペクト ルを求めるための堌幅率に相当する。小林らは初めにこ の $G_{\mathrm{S}}(T)$ を求め，この影響を観測記録から除いてその 他の係数 $A(T), B(T)$ 预よび $C(T)$ を得ている。

同種の解析を目的として筆者らが試験的に 56 種類の 強震記録を用いて，この $G_{S}(T)$ の值を求めてみた結果 では，最初に仮定する $G_{\mathrm{S}}(T)$ の初期值 。 $G_{\mathrm{S}}(T)$ の設 定值を種々変えると，イテレーションで最終的に収れん する $G_{\mathrm{S}}(T)$ の值も変動することが判った。つまり，イ テレーションによって収れんした最終的な $G_{\mathrm{S}}(T)$ の值 は, 初期值。列 $(T)$ を適切に設定しなければ，その初期 值: ${ }_{0} G_{\mathrm{S}}(T)$ 飞従属する場合があり得るのではないかと 懸念された。幸い本論文において対象としている強震記 録はず゙て硬質地盤上で得られたものであるので表層地 盤の動特性による応答スペクトルへの影響は比較的少な く, 名つ得られた強震記録の各少イト固有の特性の相違 は工学的には有意な差を生じないのではないかと言う判 


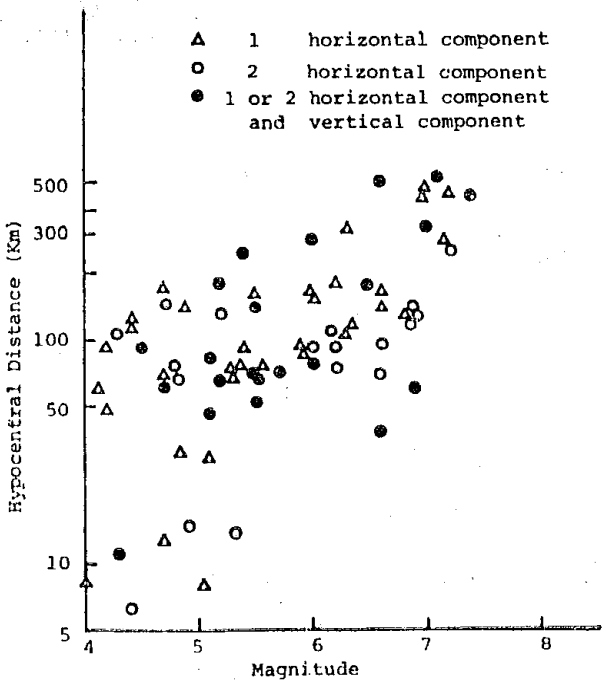

Fig. 2-1 Relation between Magnitudes and Hypocentral Distances of Data on Rock Sites

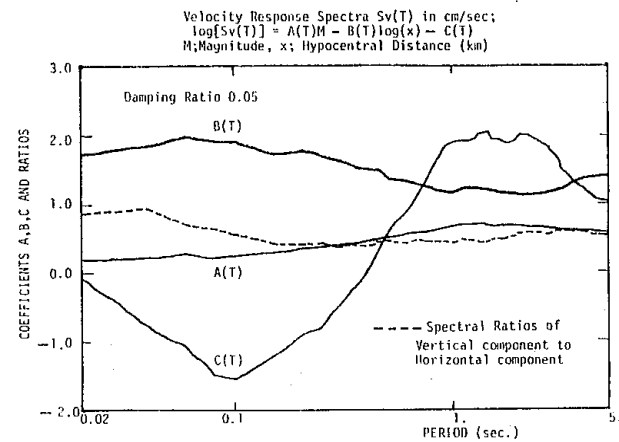

Fig. 2-2 Coefficients A, B and C (solid lines), and Ratios of Response Spectrum in Vertical component to Horizontal One (dotted line)

断のもとに, 以下の硬質地盤上の速度応答スペクトルに 関する解析においては $G_{\mathrm{S}}(T)$ の項を考慮しないことに する。

使用する地震記録を前報〉の 4 -2 項で示した硬質地盤 上の水平成分の地震記録（Fig. 2-1）だけに限定し, 式 (2-1) の $G_{\mathrm{S}}(T)$ の項を 1.0 として，硬質地盤上にお ける標準的な速度答スペクトルを求めた。得られた係 数 $A(T), B(T)$ 扝よび $C(T)$ を Fig. 2-2 に実線で 示寸。この係数から得られる震源距離 $50 \mathrm{~km}$ での種々 のマグニチュードの值についての硬質地盤上の地震動の 速度応答スペクトルを Fig. 2-3 に実線で示す。同様の 态答スペクトルをマグニチュード 8.0 での種々の震源距 離について Fig. 2-4 に実線で示す。これらの図から以 下のことが認められる。

(i ） Fig. 2-2 に示されたマグニチュードの項の係 数 $A(T)$ は 0.1 秒付近の短周期での值に較べ 1 秒付近 での值が大きく，一方震源距離の項の係数 $B(T)$ 注逆 の傾向にある。この傾向は短周期での性状を表わすと考 えられる最大加速度值と，1 秒付近での性状を表わすと 考えられる最大速度值についての，前報で同し資料学使 って得られた式 (4-3) と式 (4-4), 兩式のマグニチード

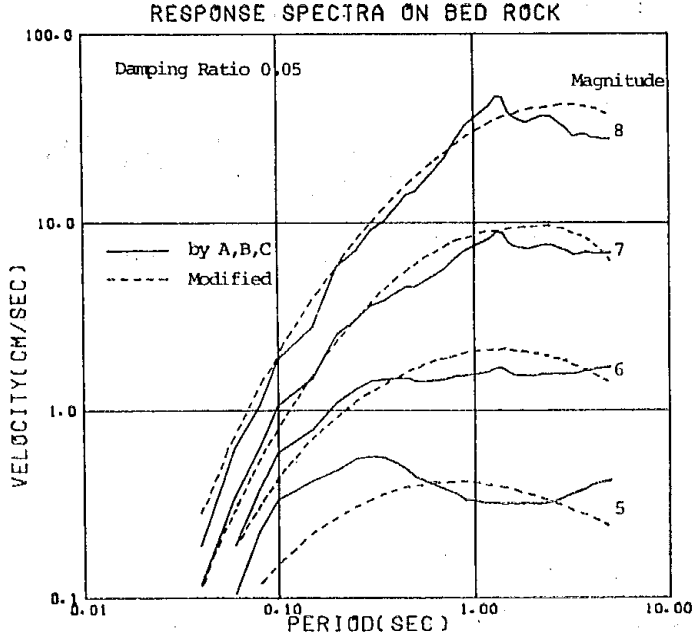

Fig. 2-3 Velocity Response Spectra on Rock Site at Hypocentral Distance $50 \mathrm{~km}$

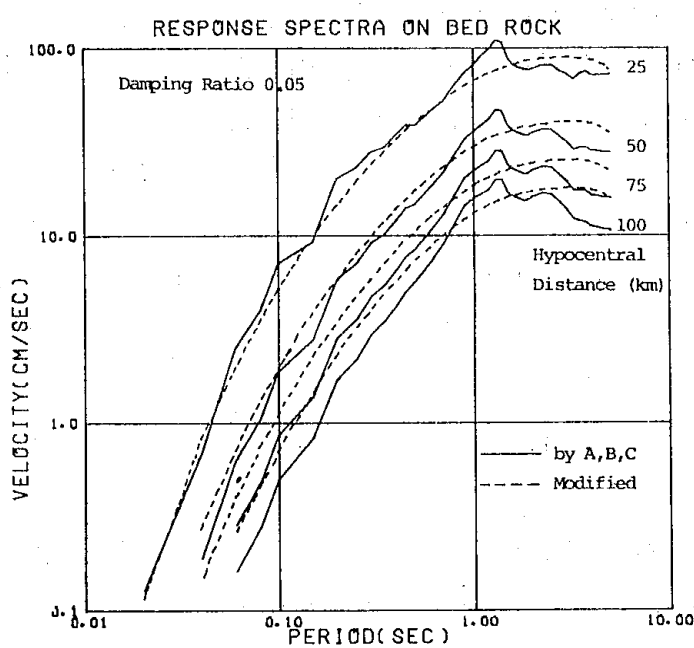

Fig. 2-4 Velocity Response Spectra on Rock Site at Magnitude 8

と震源距離それぞれの項での係数と同様の傾向を有して いる。

(ii) マグニチュードの增大とともに速度応答スペク トルが最大または一定となる周期が長くなる傾向にあ る。

（iii） 速度応答スペクトルの形状についての震源距離 の影響は小さい。

Fig. 2-2 の係数 $A(T), B(T)$ 扝よび $C(T)$ の精度 は，各観測記録のマグニチュードと震源距離を式 (2-1) に代入して得られる推定值と奏際の忘答スペクトル值を 比較することによって判断されよう。上記の推定值と観 測值の対数值を变数として得られたそれら二量間の相関 係数と両者の差を変数として得られた 標準偏差は 0.04 〜5 秒の周期領域に拎いて平均的にそれぞれ約 0.8 およ び 0.5 である。

ところで Fig. 2-3 または Fig. 2-4 の実線からわか るように，式（2-1）の仮定のもとに得られた岩盤上に 小壮る応答スペクトルは，資料の不足にもよるが平滑で はなく実用に供するには值の変動が大きすぎるだるら。 
そこで以下の断層モデルによるスペクトル形状を参考と し式 (2-1) で得られた結果をむとにした 新たな応答ス ペクトル推定式を考える。Trifunac ${ }^{(11)}$ は，震源から離 れた地点での変位スペクトル振幅量 $\left(\Omega_{F F}^{d}\right)$ として次式 を考えている。

$$
\mathscr{L}_{F F}^{d}(\omega)=\frac{L}{x} \cdot \frac{\sigma \beta}{\mu} \cdot \frac{1}{\omega^{2}+\alpha^{2}}
$$

ここに $L, \sigma, \beta, \mu$ はそれぞれ震源の断層長さ, 応力降 下，せん断波速度および剛性であり $\alpha=2.34 \beta / L$ とし ている。この式 (2-2) に $Q$ 值による波動伝播径路での 減衰項を加えて, 更に $\omega^{2}$ を乗じて加速度スペクトル用 に変形すると次式となる。

$$
\Omega_{F F}^{a}(\omega)=\frac{L}{x} \cdot \frac{\sigma \beta}{\mu} \cdot \frac{\omega^{2}}{\omega^{2}+\alpha^{2}} \cdot \exp \left(-\frac{\omega x}{2 Q \beta}\right)
$$

上式における断層長さ $L$ の対数值はマグニチュードと 線形関係にあるとされている ${ }^{122}$ が，この断層長さ $L$ と 震源距離 $x$ を変数とした上式は低周波数になるに従い減 少し断層長さ $L$ が小さくなるほどその減少が著しい関 数 $\omega^{2} /\left(\omega^{2}+\alpha^{2}\right)$, 拉よび高周波数になるに従い減少し震 源距離 $x$ が大きくなるほどその減少が著しい関数 exp $(-\omega x / 2 Q \beta)$ によって構成されている。一方, 地震動 の加速度フーリエ振幅スペクトルと非減衰の速度応答ス ペクトルが類似であると考えれば上式の有する特性を速 度応答スペクトルの特性の推定に適用することができ る。

式 (2-1) の表現で得られた Fig. 2-2 に示される係数 $A(T), B(T)$ は長周期領域においてほぼ一定であり, それらの值が (その1) で得られた式 (4-4) の最大速度 值のマグニチュードと震源距離のそれぞれの項の係数 0.607 と 1.19 にほぼ一致することを考慮して, この岩 盤上に打ける速度応答スペクトルを次式で仮定する。

$\log S_{v}(M, x, \xi, T)=0.607 M-1.19 \log x$

$$
-1.15+g_{1}(M, T)-g_{2}(x, T)+g_{3}(\xi, T)
$$

ここで $g_{3}(\xi, T)$ は減衰定数 $\xi$ についての補正項であ りここでは下式のような Rosenblueth による補正率131 を用いる。

$$
\begin{aligned}
g_{3}(\xi, T)= & \frac{1}{2} \log [\{\text { loge } 2.72(4 \pi n \xi / 1.78+1)\} \\
& \times\{1-\exp (-4 \pi n \xi)\} / 4 \pi n \xi]
\end{aligned}
$$

ここで $n=T_{\mathrm{eq}} / T$ であり， $T_{\mathrm{eq}}$ は地震動を定常なもの とした場合のそれの継続時間であり次章で示す式 (3-6) を用いている。次に Fig. 2-2 の係数 $A(T), B(T)$ お よび $C(T)$ を使って得られる種々のマグニチュードと 震源距離々招ける減衰定数 $5 \%$ の応答スペクトルの值を 近似できるよ5に式 (2-4)の $g_{1}(M, T)$ と $g_{2}(x, T)$ を 次式と定める。

$$
\begin{aligned}
g_{1}(M, T)=a_{1}\left\{1-\left(T / a_{2}\right)^{a_{3}}\right\}\left\{1+T \exp \left(1-a_{4} T\right)\right\} \\
こ こ \text { }, a_{1}=0.015 /(M / 8)^{14}+0.055 \\
a_{2}=0.045 \times 1.6^{M} \\
a_{3}=1.8 \times(M / 8)^{13} /\left\{(M / 8)^{13}+0.15\right\} \\
a_{4}=0.1 /(M / 8)^{15}+0.9 \\
g_{2}(x, T)=0.25 x^{0.1}(1 / \sqrt{T}-1)
\end{aligned}
$$

以上平滑化を目的とする速度応答スペクトルの基本 式, 式 (2-4) に $g_{1}, g_{2}, g_{3}$ の值を定める式 (2-5) と式 (2-6) および $T_{\mathrm{eq}}$ を定める式 (3-6) を使って平滑化し た速度応答スペクトルの図を Fig. 2-3 挍よび Fig. 2-4 に破線で示す。これらの図の実線は式 (2-1) を使って係 数 $A(T), B(T), C(T)$ 加救めた平滑化していない 速度応答スペクトルである。擬似加速度応答スペクトル についても同様の図を Fig. 2-5 および Fig. 2-6 に示 す。以上の Fig. 2-3〜Fig. 2-6 の図によって式 (2-4) 〜式 (2-6) を使って推定されたスペクトル值はマグニ チュードの小さい場合打よび震源距離が大きい場合の短 周期領域を除いて，式 (2-1) から得られる應答スペク トル值を近似的に平滑化している。一方, 式 (2-4) に よって推定される減衰定数 $5 \%$ での速度応答スペクトル の最大值または一定と考えられる領域でのスペクトル值 と（その 1) で得られた式 (4-4) から推定される最大速

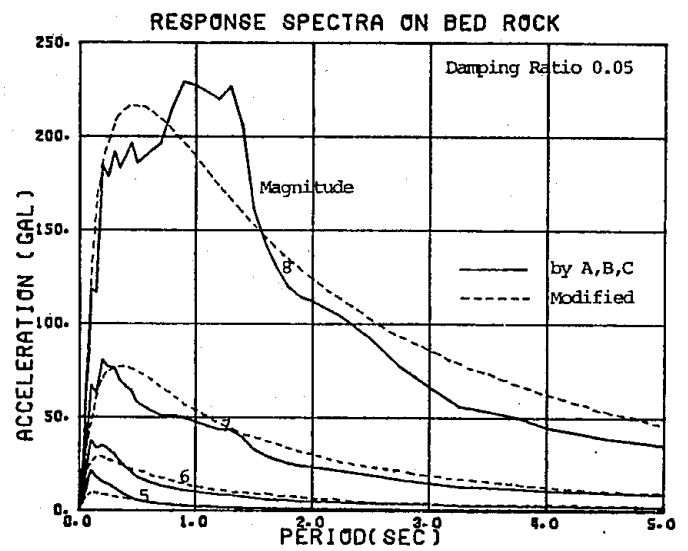

Fig. 2-5 Psuedo Acceleration Response Spectra on Rock Site at Hypocentral Distance $50 \mathrm{~km}$

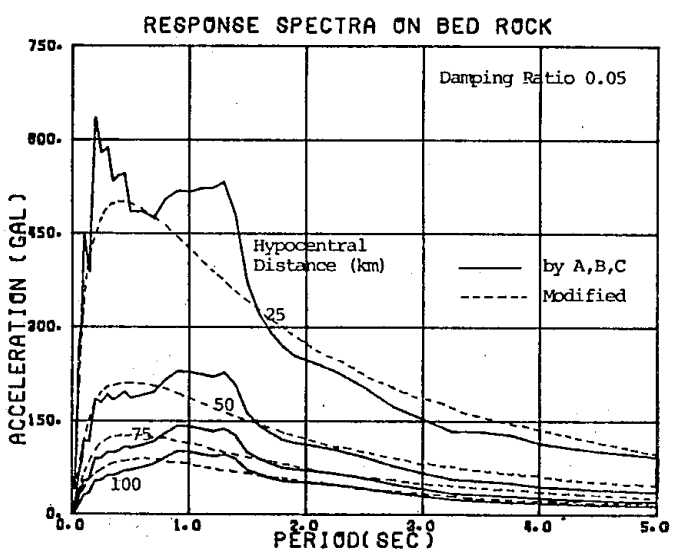

Fig. 2-6 Psuedo Acceleration Response Spectra on Rock Site at Magnitude 8 
度值を比較すると, 応答倍率は約 $1.3 \sim 1.6$ である。通 常個々の地震記録についての減衰定数 $5 \%$ で速度応答 倍率は 2.0 前後であるから上記の高答倍率はそれと較べ ると小さい。これは最小二乗法を各周期について適用し たことやスペクトル領域での平滑化を行ったことによっ て結果的に応答倍率が小さいもの亡なったと考えられ る。(その 1)の 4.3 項で式 (4-4) と金井の提案式を比 較した結果から, 速度応答倍率に関しては本章で提案し た速度応答スペクトルは金井の提案した最大速度推定式 に対応している。

上下成分のスペクトル特性を上述の解析と同様にして 求める目的に適切な観測記録は水平方向 74 種に対しわ ずか 8 種であることが予備解析から判明した。 74 種の 水平方向成分の観測資料数に対しても前述のよらに円滑 なスペクトルが得られす資料数が十分とは考えられない ことから，8 種の観測記録によって水平方向と同様の解 析を行うことは結果の信頼性に沉しいものとなろら。本 論では同一記録の各周期に打ける水平方向と上下方向の 応答スペクトル值の比をとってこれら各周期における比 を 8 種の記録に対して平均することによって，上下動の スペクトル特性を求めることとした。このように各周期 に対して上記の平均值を求めた結果を Fig. 2-2 に招け る破線で示す。

この Fig. 2-2 から各周期における減衰定数 $5 \%$ での 上下動の速度忘答スペクトル值の水平動のそれに対する 比は 0.15〜1.5 秒の周期範囲で約 0.45 であり，これ以 外の周期, 特に 0.15 秒以下のより短い周期では 0.45 よりかなり大きく約 $2 / 3$ となっている。このスペクトル 比は Trifunac による観测記録を使用した加速度フーリ エ振幅スペクトルについての同種の解析結果 ${ }^{8)}$ と良く対 応し，上下動成分の周波数領域における主要部は水平動 成分のそれに較べ平滑であり，より短周期成分を多く含 んでいることが判る。このスペクトル比はマグニチュー ドや震源距離に影響されるものであるが，上下動成分の 観測資料の少ない現在に掠いては第 1 近似としてこの結 果を用いることもやをを得ないであろら。

Fig. 2-7 と Fig. 2-8 注実記録の速度态答スペクトル と式 (2-4) および Fig. 2-2 のスペクトル比を平滑にし たものを使って推定した水平動と上下動の応答スペクト ルを比較したものである。これらの図は特に水平 2 成分 上下 1 成分の 3 成分同時記録のある観測資料を選んで比 較したものであるが，標準的なものとして推定されてい る計算値性観測值を量的に良く再現している。

これまでに紹介してきた応答スペクトルについての記 述は減変定数が $5 \%$ に対するものである。以下には $5 \%$ の減衰定数以外の值を有する応答スペクトルを求める方 法についての研究を紹介する。

Fig. 2-9 に示す破線は Fig. 2-1 に示した岩盤におけ

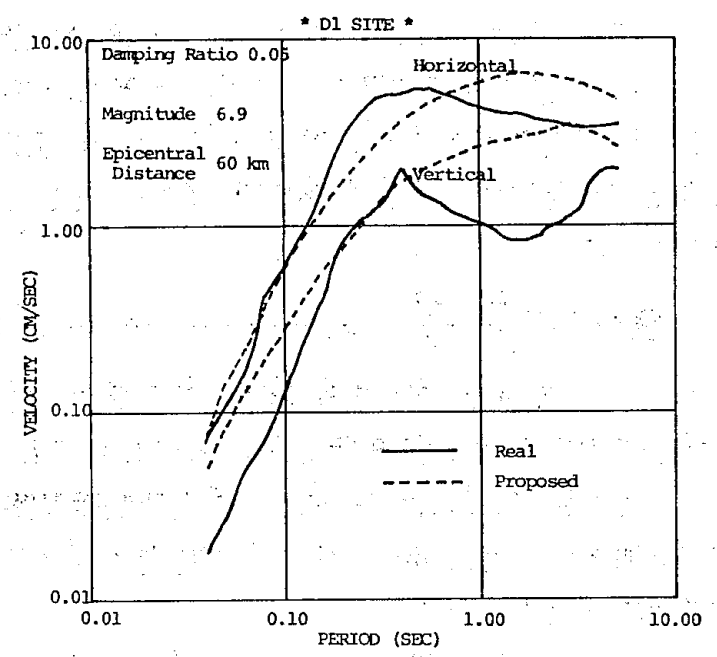

Fig. 2-7 Response Spectra due to Real Earthquake and Calculated Ones on D 1-Site

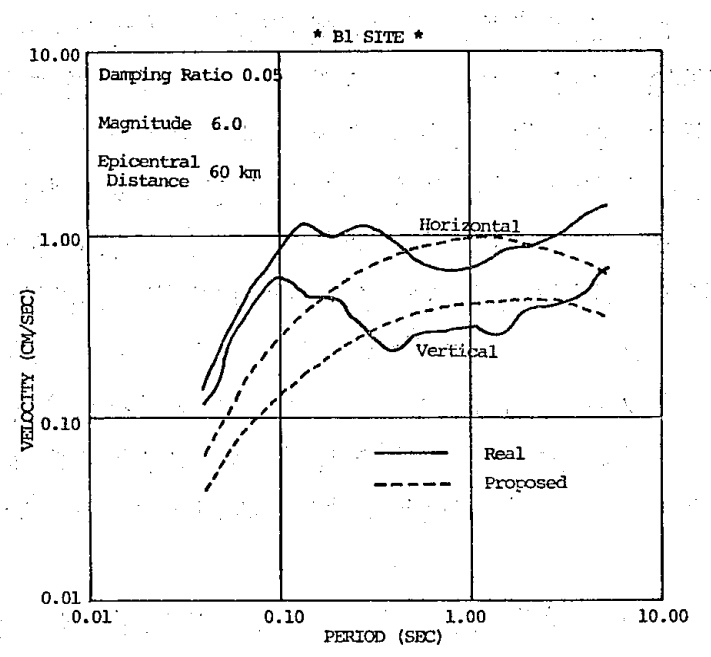

Fig. 2-8 Response Spectra due to Real Earthquake and Calculated Ones on B 1-Site

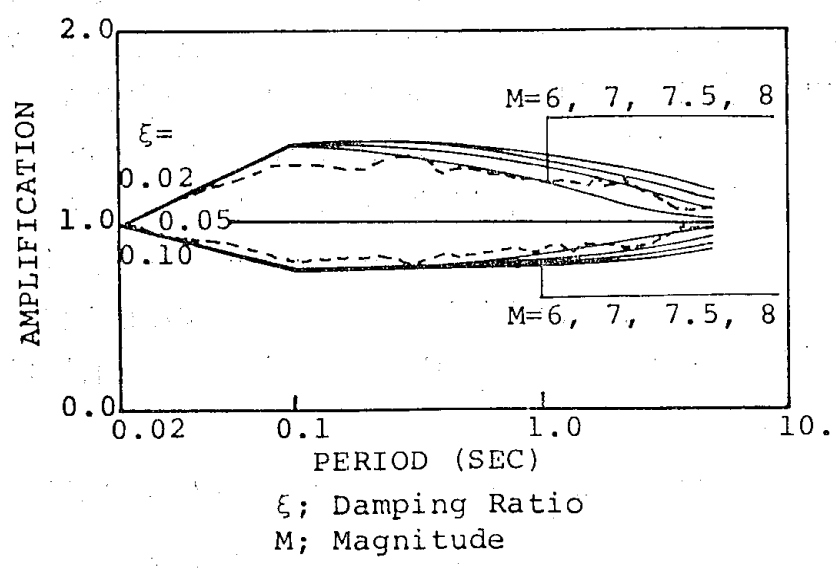

Fig. 2-9 Effect of Damping, Normalized by Response with 5\% Damping

る地震記録中の全水平成分について, 減衰定数 $5 \%$ の态 答スペクトル值に対する減衰定数 $2 \%$ および $10 \%$ の忘 答スペクトル值の比を各周期に晾いて求めてこれらの比 を各周期毎に平均した值である。この減衰定数 $5 \%$ の応 答スペクトル值に対する任意の減衰定数 $\xi$ のそれの比 $\eta$ をある式で表わすことを考える。この式を表現する変 
数としては不規則振動の最大応答值を推定する理論式 ${ }^{\text {13) }}$ のパラメータである減衰定数と応答の等価な波数を意味 する，定常と仮定した地震動の継続時間 $T_{\mathrm{eq}}$ と固有周 期 $T$ の比を使用することとする。この変数を使って上 記 Fig. 2-9 の図に破線で示す結果をできる限り近似さ せるよらに定めたものが下式である。

$$
\eta= \begin{cases}1 / \sqrt{1+17(\xi-0.05) \exp \left(-2.5 T / T_{\mathrm{eq}}\right)} \\ 1 & ; T \geqq 0.1 \mathrm{sec} \\ 1 & ; T=0.02 \mathrm{sec}\end{cases}
$$

$T_{\text {eq }}$ については式 (3-6) で与完られるマグニチュード を変数とした式を用いる。種々のマグニチュードについ て得た式 (2-7) による $\eta$ を. Fig. 2-9 に実線で示す。 この図からマグニチュードが大きい，才なわち継続時閒 が長いと長周期での減衰定数による応答スペクトルの変 化が大きくなることがわかる。Fig. 2-1 に示した上下 動成分についても同様の解析を行っているが，これによ る結果も Fig. 2-9 の破線と同様の傾向を示している。

\section{§3. 地震動の継続時間亡確定強度関数}

地震の規模が大きくなるに従い破断断層は長くなる が，一方その破断速度は地震の規模にかかわらずほぼ一 定であるとされている。従って地震動の継続する時間は マグニチュードと密接な関係があろう。松田によると主 断層の長さ $L(\mathrm{~km})$ i $^{14)}$

$$
\log L=0.6 M-2.91
$$

とされているが，仮にこの断層が等速 $3 \mathrm{~km} / \mathrm{sec}$ で破断 すると仮定すれば，その破断に要する時閒 $T_{r}(\mathrm{sec})$ 注次 式となる。

$$
\log T_{r}=0.6 M-3.38
$$

この推定值は仮定より地震動の主要動部の継続時間と考 えることができる。

観測記録を使用して地震動の継続時閒を定める場合; 地震動がどの状態に至ったときを初めとし，どの状態に 至ったときを終りとするかの定義が一定していないため 種々の提案者によって值に相当のばらつきがある。この 観測記録による地震動の継続時間 $T_{d}(\mathrm{sec})$ とマグニチ ニードの関係式の一つとして次式がある ${ }^{155}$ 。

$$
\log T_{d}=0.31 M-0.77
$$

ここで各加速度記録の継続時間は立上がり時間からピー ク值の $10 \%$ になる減衰部の時閒までとされている。式 (3-2) と式 (3-3) による継続時間以外に Housner ${ }^{16)}$ お よび Vanmarcke ${ }^{17)}$ による提案を加えてマグニチュード と継続時閒の関係を示したものが Fig. 3-1 である。 Housner と Vanmarcke の研究江観測記録を資料として 用いて和りそれらの提案はそれぞれ式 (3-3) と式 (3-2) に対応するものと考えられる。この Fig. 3-1 によると マグニチュード 8 の場合には継続時閒は $35 \sim 50$ 秒とな り主要動部の継続時間は 20２5 秒となる。

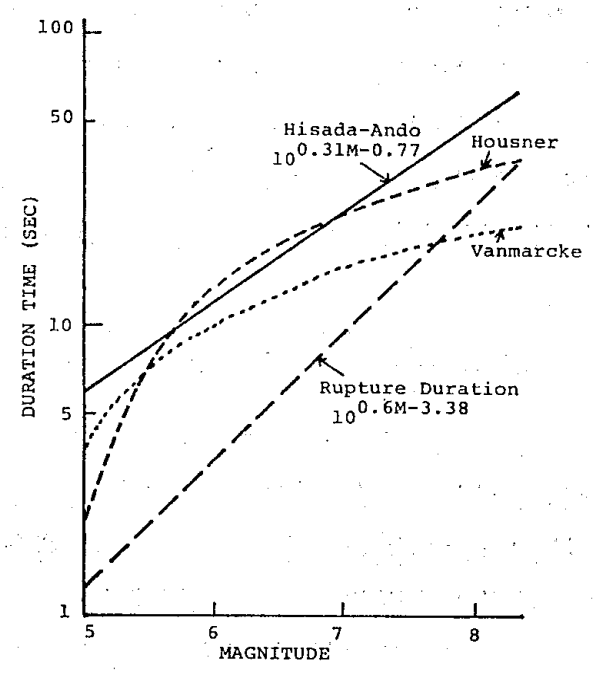

Fig. 3-1 Relationship between Magnitudes and Duration Times of Earthquakes

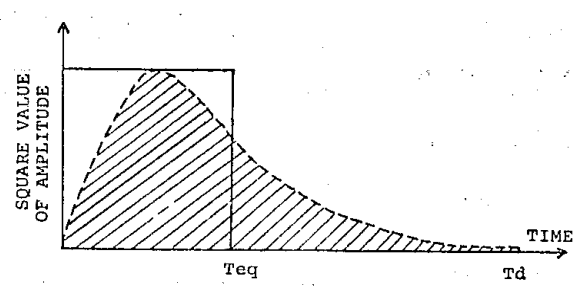

Fig. 3-2 Schema for Equivalent Duration Time

な扔本論では地震動を定常なものとして扱うほうが便 利な場合に, 式 (3-3) を变形した定常な地震動の継続時 間 $T_{\mathrm{eq}}$ を用いている。地震動の全パワーは地震動の強 さを代表する 1 つの量 ${ }^{20)}$ と考光られるから，この全パワ 一を指標として以下のように $T_{\mathrm{eq}}$ を定める。

まず非定常な地震動の包絡線 $\zeta(t)$ の継絸時間 $T d$ ま での二乗和すなわち全パワーを求める。もう一方とし て， $\zeta^{2}(t)$ の最大值を一定な值として有する継続時間 $T_{\mathrm{eq}}$ の地震動を考える。この両者の全パワーが等しく なる $T_{\text {eq }}$ を定常な地震動の継続時閒とする (Fig. 3-2)。 すなわち

$$
T_{\mathrm{eq}}=\int_{0}^{T_{d}} \zeta^{2}(t) d t /\left|\zeta^{2}(t)\right|_{\mathrm{max}}
$$

ここでは前報 (その1) と斿ける Fig. 2-6, Table 2-2 参照して

$$
\left.\begin{array}{l}
\zeta(t)=t \cdot \exp (-a t) \\
\text { かつ } \\
\zeta\left(T_{d}\right)=0.1, \\
t_{\mathrm{max}} / T_{d}=0.2\left(\zeta\left(t_{\mathrm{max}}\right)=|\zeta(t)|_{\text {max }}\right)
\end{array}\right\}
$$

を仮定する。このとき $T_{\mathrm{eq}} \doteq 0.37 T_{d}$ となり $T_{d}$ に式 (3-3) を代入すると次式となる。

$\log T_{\text {eq }}=0.31 M-1.20, T_{\text {eq }}: \mathrm{sec}$

非定常模擬地震動の時閒領域におけるもら一方の重要 な要素は確定強度関数である。(その1)の 2.4 項で述 べたようにこの方面の研究は多くみられるが，ここで観 測記録から確定強度関数を抽出するために以下の手法を 導入し，確定強度関数を定式化するための資料とする。 
強震加速度記録 $\ddot{y}(t)$ が, 次式に示すように確定強度 関数 $\zeta(t)$ と定常ガウス・ランダム過程 $\ddot{y}_{S}(t)$ によって

$$
\ddot{y}(t)=\zeta(t) \cdot \ddot{y}_{S}(t)
$$

と表現されるとする。ここで，ある時間区分 $\Delta t$ をとり 次の移動平均操作を加えて $\Delta t$ 亿関する確定強度関数を 求める。

$$
\zeta(t, \Delta t)=\left[\frac{1}{\Delta t} \int_{t-\Delta t / 2}^{t+\Delta t / 2} \ddot{y}^{2}(\tau) d \tau\right]^{1 / 2}
$$

次に $\ddot{y}(t)$ を $\zeta(t, \Delta t)$ によって除して得られる $\ddot{y}_{S}(t$, $\Delta t)$ に対してガウス分布の検定 ( $x^{2}$ の検定) と定常ラン

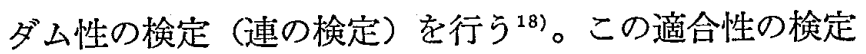
を満足する移動平均操作のための時間区分 $\Delta t$ を試行錯 誤によって求めて, その結果を原記録 $\ddot{y}(t)$ の確定強度 関数とする。Fig. 3-3 は乞の一例である。

この手法を上下成分も有する米国で得られた強震記録 18 種 (Table 3-3) に適用して, 得られた各確定強度関 数 $\zeta(t)$ を継続時間 $T_{d}$ および $\zeta(t)$ の全面積で次のよ うに無次元化する。

$$
\begin{aligned}
& \widetilde{\zeta}(\tau)=100 \cdot \zeta(t) / \int_{0}^{100} \zeta(\tau) d \tau \\
& \tau=100 \cdot t / T_{d}
\end{aligned}
$$

この無次元化された確定強度関数 $\widetilde{\zeta}(\tau)$ の累積分布 $A(\tau)$ を Gompertz の曲線を変形した次式と仮定する。

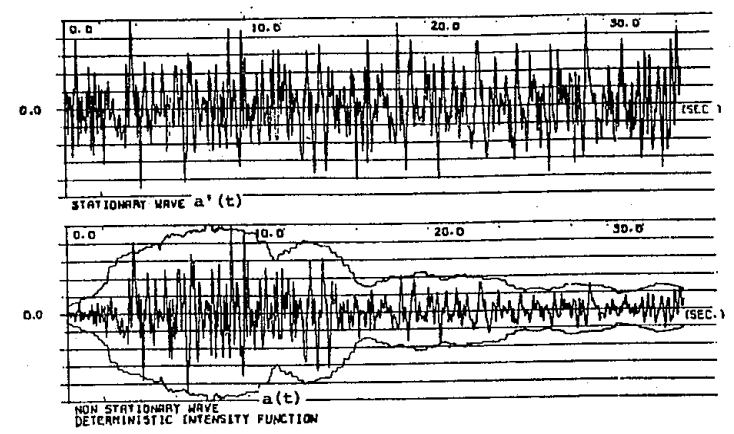

Fig. 3-3 Deterministic Intensity Function

\begin{tabular}{|c|c|c|}
\hline EARTHQUAKE & STATION NAME & DATE \\
\hline Imperial valley & El-Centro & May 18,1940 \\
\hline Kern County, Calf. & Taft Lincoln S.T. & Ju1. 21, 1952 \\
\hline San Jose & San Jose Bank A. & Sep. 4,1955 \\
\hline El-Alamo,Baja Calf. & El-Centro & Feb. 9,1956 \\
\hline San Francisco & S.F.Golden Gate Park & May 22,1957 \\
\hline Borrego Mountain & El-Centro & Apr. 8,1968 \\
\hline Southern Calf. & $\begin{array}{l}\text { Hollywood Storage } \\
\text { Bldg }\end{array}$ & oct. 2,1968 \\
\hline Lower Calf. & El-Centro & Dec. 30,1934 \\
\hline Western Washington & O.W. Hwy Test Lab. & Apr.13,1934 \\
\hline Wheeler Ridge, Calf. & Taft Lincoln S.T. & $\operatorname{Jan} .12,1954$ \\
\hline puget sound $w$. & O.W.Hwy Test Lab. & Apr. 29,1965 \\
\hline Parkfield,Calf. & C.S.Calf.ARRAY.NO. 5 & Jun. 27,1966 \\
\hline San Fernando & $\begin{array}{l}\text { Lake Hughes, Array } \\
\text { Station } 12 \text {, Calf. }\end{array}$ & Feb. 9,1971 \\
\hline Imperial Valley & $\begin{array}{l}\text { El-Centro } \\
\text { Elati. }\end{array}$ & Dec.16,1955 \\
\hline Long Beach & $\begin{array}{l}\text { L.A.Subway } \\
\text { Terminal,Los-Ang. }\end{array}$ & May 10,1933 \\
\hline Torrance-Gardena & $\begin{array}{l}\text { Chamber of Commerce } \\
\text { Los } \rightarrow \text { Ang. }\end{array}$ & Nov 14,1941 \\
\hline Northern-Calf. & Pacific Tel.Bldg & Sep.12,1966 \\
\hline Lytle creek & J.P.Lab.,Pasadena & Sep.12,1970 \\
\hline
\end{tabular}
of Taft-EW

Table 3-1 Accelerograms of Data for Deterministic Intensity Function

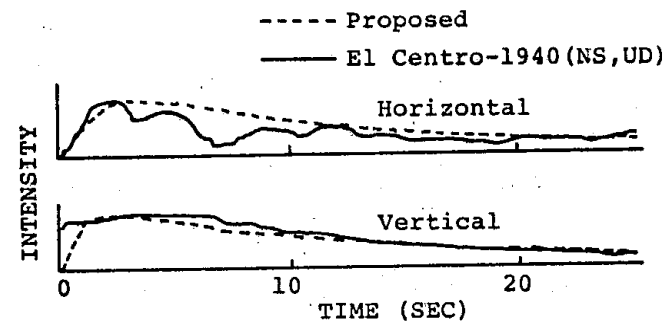

Fig. 3-4 Calculated Deterministic Intensity Functions (dotted lines) and Observed Ones (solid lines)

$$
A(\tau)=\int_{0}^{\tau} \widetilde{\zeta}(\tau) d \tau=a^{b^{\tau c}}
$$

18 種の資料に上式を当てはめて最小二乗法から得られ た累積分布を，微分して求めた水平動成分と上下動成分 の無次元化した確定強度関数は次式となる。

$$
\begin{aligned}
\log \tilde{\zeta}^{h}(\tau)= & 1.08+2.13 \times 0.056^{\tau^{-0.3 .4}} \\
& -1.25 \times \tau^{-0.84}-1.84 \log \tau \cdots(3-12) \\
\log \tilde{\zeta}^{v}(\tau)= & 0.81+2.22 \times 0.140^{\tau^{-0.84}} \\
& -0.85 \times \tau^{-0.84}-1.64 \log \tau \cdots(3-13)
\end{aligned}
$$

ここで $\tau$ は式 (3-10) で示す全継続時間に対する百分率 であり， $h, v$ はそれぞれ水平，上下成分を示す。この 2 種の関数の最大值は，水平成分については $\tau=6.5$ で 3.13 また上下成分については $\tau=4.5$ で 2.90 ，となる。 Fig. 3-4 に打汀る実線は El Centro-NS, UD 成分につ いて上述の実記録から確定強度関数を求める手法を適用 して得られた結果であり，同図の破線は $\tau$ が 100 となる 時間を 50 秒と仮定して式 (3-12) と式 (3-13) から求 めた結果である。この図から上下成分の確定強度関数が 水平成分のそれより立上がりが早くまた平担であること がわかる。ここで最大值の $10 \%$ に至った時間を地震動 終了としている式 (3-3) による継続時間を式 (3-12) ま たは式 (3-13) に適用する場合には，その継続時間が上 式の $70 \%$ 程度の無次元化時間 $(\tau=70)$ に相当すると仮 定するのが適当である。

\section{§4. 実地震動の 3 次元成分の主軸方向についての特 性}

地震動の主軸方向 ${ }^{10}$ についての特性で重要な要素は主 軸方向の地震動と観測された地震動との相関性, 各主軸 方向成分のスペクトル特性, 各主軸方向成分の相対的な 強さの関係等である。San Fernando 地震 (1971, マグ ニチニード 6.6）の記録を解析した結果 ${ }^{19)}$ 打よび Fig. 2-1 の岩盤での記録中，水平 2 成分上下 1 成分の同時記 録を有する 11 の記録を解析した結果を整理して上述の 特性の一般的な傾向が以下に示されている。Fig. 4-1 は San Fernando 地震による 23 種の地震動について 5 秒間の間隔の移動平均操作によって求められた非定常性 を考慮した時間每の分散值でそれが全時間中に最大とな る時間での結果，また岩盤記録では全継続時間に対して 得られた結果であり合計 34 種について鉛值軸からの主 


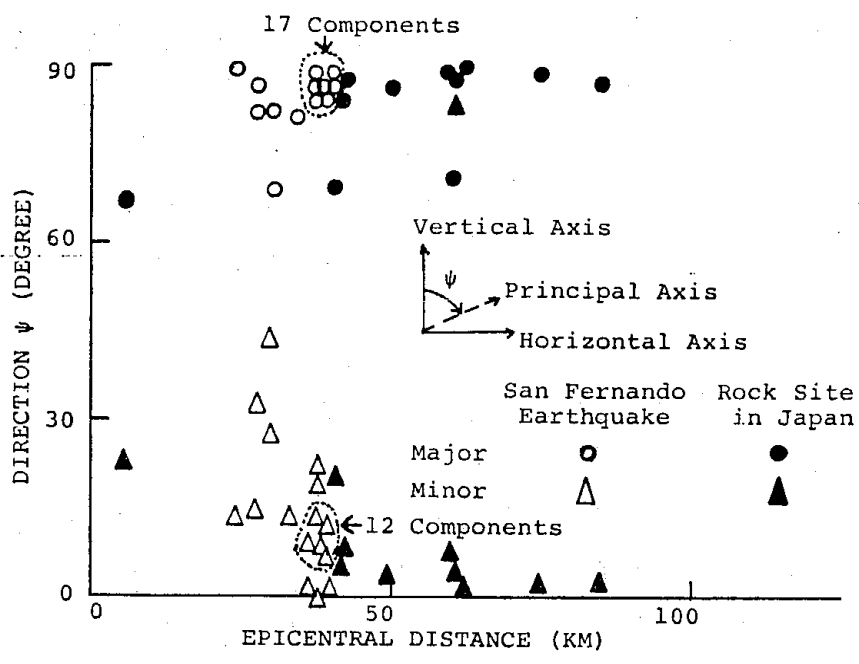

Fig. 4-1 Relationship between Epicentral Distance and Direction of Earthquake along Principal Axis

Table 4-1 Ratios of Intermediate and Minor Principal Variances to Major One

\begin{tabular}{|c|c|c|c|}
\hline \multicolumn{2}{|c|}{ RECORD } & San Fernando & Rock Site \\
\hline \multirow{2}{*}{$\begin{array}{l}\vec{\pi} \\
\stackrel{\tilde{\omega}}{2}\end{array}$} & Inter & 0.61 & 0.51 \\
\hline & Minor & 0.17 & 0.18 \\
\hline \multirow{2}{*}{ 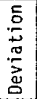 } & Inter & 0.18 & 0.17 \\
\hline & Minor & 0.07 & 0.12 \\
\hline
\end{tabular}

軸の傾き（図中の $\phi$ ) を示したものである。ここで $\phi$ が $0^{\circ}$ のときは主軸が鉛直方向を, $90^{\circ}$ のときは水平面の方 向を向いていることを示す。Table 4-1 ほ，各記録の分 散值の最大値に対する中閒值 (Intermediate) および最 小值の比を求めて, 平均值および標準偏差を San Fernando 地震と岩盤記録各々について求めたものである。

これらの結果から次のことが言える。

(i) 分散值が最大值をとる主軸 (major principal axis）汇注水平面内に含まれる。すなわち，地震 の強度の最も強い方向は水平面内方向である。

(ii) 分散值が最小值をとる主軸 (minor principal axis）注震源距離が $50 \mathrm{~km}$ 以上の值をとる地点で は，ほぼ鉛直方向を有し，震源距離が上記の值より 小さくなるにつれ水平面への傾きを増し，その結果 最大主軸または中間主軸が鉛直方向を指向する傾向 が認められる。すなわち，震源に近い地点では鉛植 方向の地震の強度が水平方向のそれと同等となる傾 向有する。

（iii）以上から，三次元模擬地震動をそれぞれ独立の 過程として主軸に沿って作成するとき, 震源近傍の 地域を除いて最大主軸，中間主軸の二主軸忹水平面 内に含まれ，最小主軸鉛直方向を指向すると仮定 することができる。

(iv) 各主軸成分の分散值の比率の前述 34 種の地震 動についての平均は,

最大分散值: 中間分散值: 最小分散值 $=1.00: 0.55$ :
0.18 である。この分散值は物理的な量としては地 震動のエネルギーに対応する量であり一つの地震動 の強さ (intensity) を表わす ${ }^{20)}$ も考它られる。 その物理的な意味からすれば，従来よく用いられて きた最大加速度, 最大速度, Housner のスペクトル 強度といった地震動の強さの指標とは平方根によっ て結ばれるものと考えられるがら，従来の地震強度 の指標值に換算すれば，三主軸閒の強度比はほぼ $1.00: 0.74: 0.42$ の比率関係を有するとみなされ よう。

ある地震記録を対像とした水平 1 次元入力による応答 解析に扔いては，通常，その地震記録の水平 1 成分を対 象構造物の解析モデルへの入力として取り扱っている。 ところで 1 次元入力に限定した場合にあっても，入力地 震動としては対象とする地震記録の 2 直交成分によって 定義される，あらゅる方向でのベクトル和をとりらる。 このベクトル和の分散の最大值をとる方向は, 水平 2 直 交成分の主軸の方向となるわ付である。以下では，地震 動の 2 直交成分によるべクトル和と，それによる念答值 との関連性について検討することによって，応答に対し ての地震動の主軸方向の意義を述べる。

地震記録の水平面内 $\mathrm{NS}, \mathrm{EW}$ 両成分 $\ddot{y}_{\mathrm{NS}}(t)$ と $\ddot{y}_{\mathrm{EW}}$ ( $t$ ）が，観測された 2 直角座標軸のN方向より原点を中 心に右廻りに $\theta$ 回転した軸をとると，この軸方向の動き $\ddot{y}_{\theta}(t)$ は次式となる。

$$
\ddot{y}_{\theta}(t)=\cos \theta \cdot \ddot{y}_{\mathrm{NS}}(t)+\sin \theta \cdot \ddot{y}_{\mathrm{EW}}(t)
$$

この $\theta$ 軸方向に沿って振動する 1 質点系の応答值 $r_{\theta}(t)$ は

$$
r_{\theta}(t)=\cos \theta \cdot r_{\mathrm{NS}}(t)+\sin \theta \cdot r_{\mathrm{EW}}(t)
$$
ここで $r_{\mathrm{NS}}(t)$ と $r_{\mathrm{EW}}(t)$ はそれぞれ $\ddot{y}_{\mathrm{NS}}(t)$ または $\ddot{y}_{\mathrm{EW}}(t)$ のみによる応答值である。上記 $\theta$ 方向について 地震動の継続時間 $T_{d}$ 内での二乗平均值 $\overline{\ddot{y}_{\theta}{ }^{2}(t)}$ および 減衰定数 $5 \%$ に打ける擬似最大速度応答值の周期 $\left[T_{l}\right.$, $T_{u l}$ ] 区閒内のスペクトル強度 $S I_{\theta}\left(T_{l}, T_{u}\right)$ によって水 平面内での地震動と応答值の変動量をそれぞれ代表させ よう。すなわち

$$
\begin{aligned}
& \ddot{y}_{\theta}{ }^{2}(t)=\frac{1}{T_{d}} \int_{0}^{T_{d}}\left\{\ddot{y}_{\theta}(t)\right\}^{2} d t \ldots \ldots \ldots \ldots . . . . \\
& S I_{\theta}\left(T_{l}, T_{u}\right)=\int_{T_{u}}^{T_{l}} \frac{2 \pi}{T} S D_{\theta}(T) d T
\end{aligned}
$$

ここで $S D_{\theta}(T)$ は固有周期 $T$ での最大变位応答值で ある。式 (4-1) を式 (4-3) に代大すれば

$$
\begin{aligned}
& \overline{\ddot{y}_{\theta}{ }^{2}(t)}=\frac{\overline{\ddot{y}_{\mathrm{NS}}{ }^{2}(t)}+\overline{\ddot{\mathrm{EWW}}^{2}(t)}}{2}+\left[\left(\frac{\overline{\ddot{y}_{\mathrm{NS}}{ }^{2}(t)}-\overline{\ddot{y}_{\mathrm{EW}}{ }^{2}(t)}}{2}\right)^{2}\right. \\
& \left.+\left(\ddot{y}_{\mathrm{NS}}(t) \cdot \ddot{y}_{\mathrm{EW}}(t)\right)^{2}\right]^{1 / 2} \cdot \cos (2 \theta-\varphi) \\
& \varphi=\tan ^{-1} \frac{2 \overline{\ddot{y}_{\mathrm{NS}}(t) \cdot \ddot{y}_{\mathrm{EW}}(t)}}{\ddot{y}_{\mathrm{NS}}{ }^{2}(\bar{t})-\bar{y}_{\mathrm{EW}}{ }^{2}(t)}
\end{aligned}
$$


従って， $\overline{\ddot{y}_{\theta}{ }^{2}(t)}$ は周期 $\pi$ の正弦関数でありこの最大, 最 小をとる 2 直交軸はこの地震動 2 成分の主軸となる。一 方 $S I_{\theta}\left(T_{l}, T_{u}\right)$ ～も周期 $\pi$ を有するが正弦関数とはなら ない。しかし, 最大応答值は, 応答の分散に最も強く依 度するものであり，この分散は式 (4-5) と同様に周期 $\pi$ の正弦関数となることから各周期での最大応答值の $\theta$ 方 向での変動が互いに大きく異ならない限り, この $S I_{\theta}$ $\left(T_{l}, T_{u}\right)$ の変動も正弦関数に近いものと考えられる。 具体的な例として Taft 1952, EI Centro 1940 および 八戸 1968 の 3 地震記録の $[0,30]$ 秒の記録を用いる。 $S I_{\theta}$ として区閒 $[0.1,2.5$ 秒 $]$ および $[0.1,0.5$ 秒 $]$ を とって, 上記地震記録についての $\theta$ に対する分散值 $\overline{\ddot{y}_{\theta}{ }^{2}(t)}$ とスペクトル強度 $S I_{\theta}\left(T_{l}, T_{u}\right)$ の値を Fig. 4-2 に示す。ただし Fig. 4-2 においては， $\overline{\ddot{y}_{\theta}{ }^{2}(t)}$ および $S I_{\theta}\left(T_{l}, T_{u}\right)$ をそれぞれの $[0, \pi]$ 区間での平均值によ

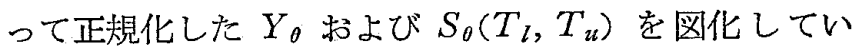
る。

この Fig. 4-2 から次のことが言える。

(i ) $S_{\theta}\left(T_{l}, T_{u k}\right)$ は上述のようにほぼ正弦関数状に 変動している。

(ii) Taft 1952 および El Centro 1940 においては $S_{\theta}(0.1,2.5)$ と $S_{\theta}(0.1,0.5)$ がともに $Y_{\theta}$ の変動 とほぼ同一の位相となっている。一方八戸 1968 に おいては $S_{\theta}(0.1,0.5)$ は比較的 $Y_{\theta}$ に似通ってい るものの $S_{\theta}(0.1,2.5)$ はほとんど逆の位相となっ ている。

以上 3 例だけでの結果であるが，この解析結果は以下 のことを示唆しているものと考えられよう。加速度記録 の最大平均パワを有する主軸の方向の成分による応答 值, 特に短周期の応答值は各 $\theta$ 方向の応答值の中で最大 值に近い值をとる。従ってある地震記録を刘象とした動 的解析に扔いて，その加速度記録の分散値が最大となる

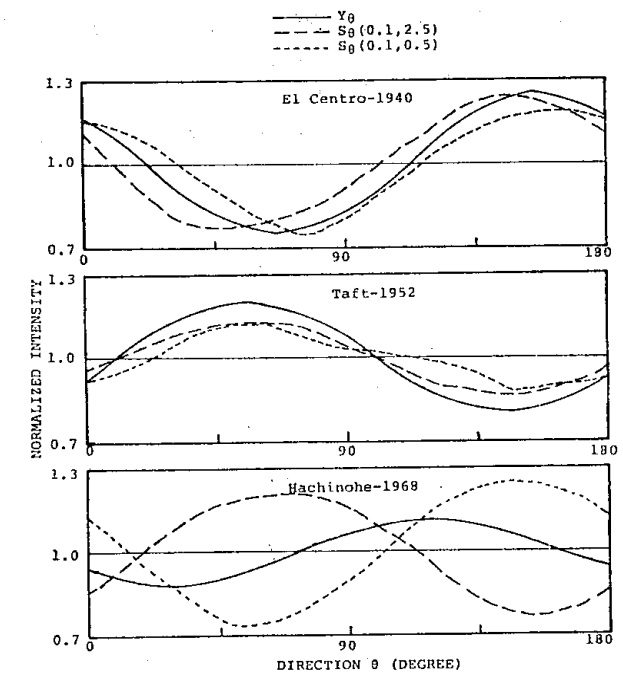

Fig. 4-2 Variation of Earthquake Variance and Spectral Intensity, in terms of Direction of Earthquake
主軸方向の成分を動的解析で対象としている水平方向に 一致させて入力すれ構造物の応答值も地震動の主軸方 向において最大となるとみなせるので，主軸方向の入力 地震動を使って応答解析を行うことは構造物の耐震安全 性を確認するうえで有效な手段と考えられよう。

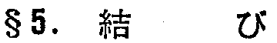

地震動のスペクトル特性, 継続時間と確定強度関数, および地震動の主軸に関する解析によって, 本報告で得 られた結果を，以下にまとめる。

5.1 岩盤における地震動のスペクトル特性について （1）マグニチュードの増大とともに, 水平動の速度 応答スペクトルの卓越する周期は長くなり, その周 期はマグニチュードが 7 以上になると 1 秒を超え る。

（2）震源距離によって，水平動の速度応答スペクト ルの絶対量はかなり変化するが, その形状に及ぼす 影響注小さい。

（3）水平動に対する上下動の速度応答スペクトルの 各周期での比の平均值は， 0.15 秒より短かい周期で は 2/3 以上となり, 特に 0.05 秒以下では, その比 は 1 亿近い。 0.15 秒から 1.5 秒の周期範囲では, 上記のスペクトル比はほぼ一定な約 0.45 の值をと る。

（4）減衰定数の変化に対する応答スペクトル值の変 動は，周期が長くなるに従って小さくなる。ただ し,これは地震動の主要動の継続する時間にも影響 される。

5.2 地震動の継続時間と確定強度関数について

（1）地震動の継続時間は，マグニチュードの増大と ともに長くなる。主要動の継続する時間の一つの目 安として,マグニチュード 7 では 10 秒前後, マグニ チュード8では 20〜25 秒と考えることができよう。

（2）地震動を式 (3-7) の数学的モデルで表現したと き， $\chi^{3}$ の検定と連の検定を用いるここで紹介した 方法は, 地震動の振幅の包絡線を意味する確定強度 関数を実地震動から抽出する有効な方法である。

（3）米国の強震記録 8 種を使って求めた水平動と上 下動の確定強度関数から，水平動よりも上下動の確 定強度関数のほうが, 立上がりが早く，また平担で あることが判る。

5.3 地震動の主軸の特性について

(1) 3 成分地震動の分散值が最大となる主軸は, ほ ぼ水平面内に含まれる。また最小值をとる主軸の方 向は，ほぼ鉛直方向であるとしてよい。

（2）主軸成分に扮ける中間分散值と最小分散值との 最大分散值に対する平均的な比率は，それぞれ 0.55 と 0.18 である。従って, 最大值やスペクトル值に 関しては，上記の值の平方根をとった 0.74 と 0.42 
がそれらの平均的な比率と考えられる。

（3）地震動の水平 2 直交成分のベクトル和による応 答值が最大となる方向とその地震動が最大パワを有 する方向（地震動の主軸）とは相関性が強い。従っ て, 構造物の動的解析に, 分散値が最大となる主軸 方向の成分を動的解析の対象方向に一致させて入力 地震動とすることは，構造物の耐震安全性をより高 めることになると考㝋られる。

以上の解析から，模擬地震動の作成に必要な地震動特 性を求めることができる。次報に执いては，これらの結 果から地震動の特性を設定して，模擬地震動を作成する 予定である。なお，以上の解析に用いた資料は必らずし も+分な数量ではない。今後は, 資料の蓄積に努力して これら地震動特性について検討を重ねていくうもりであ る。

1) 渡部 丹，藤堂正喜, “設計用模擬地震動に 関する 研究 (その 1 ; 模擬地震動の既往の数学モデルと地震動の最大 值)”日本建築学会論文報告集，第 303 号，1981

2) Kuribayashi, E., T. Iwasaki, Y. Iida and K. Tsuji, "Effects of Seismic and Subsoil Conditions on Earthquake Response Spectra", Proc. Int. Conf. on Microzonation for Safer Construction, Vol. II, 1972

3) Newmark, N.M., J.A. Blume ane K.K. Kurper, "Seismic Design Spectra Nuclear Power Plants", Proc. ASCE, Vol. 99, No. PO 2, 1973

4) Seed, H.B., I.M. Idriss and F.N. Kiefer, "Characteristics of Rock Motions during Earthquakes", EERC Reports, EERC 68-5, Univ. of California, 1968

5）小林啓美, 長橋純男, “地表で観測された地震動の周期特 性汃ら求めた地盤の堌幅特性と 地震基盤における地震動 の性質”日本建築学会論文報告集，第 240 号, 1976

6）片山恒雄, 岩崎敏男, 佐伯光昭, “地震動加速度応答スへ クトルの統計解析” 日本土本学会論文報告集, 第 275 号, 1978

7) Hisada, T., Y. Ohsaki, M. Watabe and T. Ohta, "Design Spectra for Stiff Structures on Rock", Proc.
Int. Conf. on Microzonation for Safer Construction, Vol. II, 1978

8) Trifunac, M.D., "Preliminary Empirical Model for Scaling Fourier Amplitude Spectra of Strong Ground Acceleration in terms of Modified Mercalli Intensity and Recording Site Conditions", Int. J. Earthq. Eng. Struct. Dyn., Vol. 7, 1979

9）太田 裕, 鏡味洋史, “耐震工学上考慮すべき地震波の周 期の上限と振幅の下限” 日本建築学会論文報告集, 第 249 号, 1976

10) Penzien, J. and M. Watabe, "Characteristics of 3Dimensional Earthquake Ground Motions", Int. J. Earthq. Eng. Struct. Dyn., Vol. 3, 1975

11) Trifunac, M.D., "Characterization of Response Spectra by Parameters Governing the Gross Nature of Earthquake Source Mechanisms", Proc. 5 WCEE; . Italy, 1973

12）宇津徳治, “地震学”, 共立出版, 1977

13) Rosenblueth, E. and J.I. Bustamente, "Distribution of Structural Responses to Earthquakes”, Proc. ASCE; Vol. 88, No. EM 3, 1962

14）松田時彦, “活断層から発生する地震の規模と周期にうい “”, 地震, Vol. 28, 1975

15）太田外気晴，丹羽正徳，安藤治彦，有子山直樹，“模擬地 震波作成のための地震動の最大速度と 最大加速度の関係 ならびに主要動部の継続時閒”，鹿島建設技術研究所年報 25 号, 1976

16) Housner, G.W., "Intensity of Earthquake Ground Shaking Near the Causative Fault", Proc. 3 WCEE, New Zealand, 1965

17) Vanmarcke, E.H. and P.L. Shih-Sheng, "Strong-Mo-" tion Duration of Earthquakes" Submitted to Bull. Seism. Soc. Am., 1978

13) Bendat, J.S. and A.G. Piersol, "Random Data", WileyInterscience, New York, 1971

19) Kubo, T. and J. Penzien, "Time and Frequency Domain Analysis of Three-Dimensional Ground Motions, San Fernando Earthquake", EERC Reports, EERC 76-6, Univ. of California, 1976

20) Arias, A., "A Measure of Earthquake Intensity", in Seismic Design for Nuclear Power Plants, ed. R.J. Hansen, MIT Press, 1970

\section{S Y NOPSIS}

UDC : $550.34 .042: 624.042 .7$

\section{RESEARCH ON THE DESIGN EARTHQUAKE GROUND MOTIONS}

Part-II Analysis on the characteristics of earthquake ground motions for practical generation

by Dr. MAKoTO WATABE, Director, International Institute of Seismology and Earthquake Engineering, Building. Research Institute, Ministry of Construction, and MASANOBU TOHDO, Research Member, Structural Engineering Department, Nuclear Power Division, Toda Construction Co. Ltd., Members of A.I.J.

Response spectra of the earthquake ground motions are proposed, based on the analysis of the relations among the above response spectra, magnitude and focal distance of earthquake. In latter part research on the characteristics of three dimensional earthquake ground motions is introduced. 